\title{
Working with Older People: A Qualitative Study of X and $Y$ Generation Nurses' Perceptions
}

\section{Yaşlı Bireylerle Çalışmak: X ve Y Kuşağındaki Hemşirelerin Algılarının Nitel Değerlendirilmesi}

\author{
DNeşe Uysal1, ๑Filiz Ünal Toprak², ๑Ayşegül Koç³ \\ 'Amasya University, Faculty of Health Science, Department of Nursing, Amasya, Turkey \\ ${ }^{2}$ Bolu Abant İzzet Baysal Universty, Faculty of Health Science, Department of Nursing, Bolu, Turkey \\ ${ }^{3}$ Ankara Yıldırım Beyazıt University, Faculty of Health Science, Department of Nursing, Ankara, Turkey
}

\begin{abstract}
Aim: This study aimed to compare the perceptions and working experiences of two age cohorts of nurses' about care of older people.

Material and Method: A qualitative descriptive study was used. The research sample consisted of 68 internal medicine and surgery nurses representing $X$ and $Y$ generations. Data were collected using a demographic form and a semistructured interview form. Data were subjected to thematic analysis.
\end{abstract}

Results: The general themes for generation $\mathrm{X}$ were: care time, emotional responses, and provide resources for older patients. The general themes for generation $Y$ were: increasing workload and time problems, categorization of older people, and finally, the need for holistic care.

Conclusions: All nurses experienced that caring for elderly is difficult. However, they emphasized the needs of older people. This may be an essential component in organizing older people care. It is recommended regulation of working conditions to reduce the difficulties experienced by nurses in care of older people.

Keywords: Generation, nursing care, aging, perception
Öz

Amaç: Bu çalışma, iki yaş grubundaki hemşirelerin yaşlıların bakımı hakkındaki algılarını ve çalışma deneyimlerini karşılaştırmayı amaçlamaktadır.

Gereç ve Yöntem: Bu çalışmada nitel tanımlayıcı araştırma deseni kullanılmıştır. Araştırmanın örneklemini X ve Y kuşaklarını temsil eden 68 dahiliye ve cerrahi hemşiresi oluşturmuştur. Veriler, demografik bilgi formu ve yarı yapılandııımış görüşme formu kullanılarak toplanmıştır. Verilerin değerlendirilmesinde tematik analiz yapılımıştır.

Bulgular: X kuşağı için genel temalar; bakım süresi, duygusal tepkiler ve yaşlı hastalar için kaynak sağlamadır. Y kuşağının genel temalarl; artan iş yükü ve zaman sorunu, yaşılların sınıflandırılması ve bütünsel bakıma duyulan ihtiyaçtır.

Sonuç: Tüm hemşireler yaşlılara bakmanın zor olduğunu belirtmekle birlikte yaşılıarın ihtiyaçlarını vurguladılar. Çalışma sonuçları yaşlı insanların bakımını organize etmede yarar sağlayabilir. Yaşılıarın bakımında hemşirelerin yaşadıkları zorlukları azaltmak için çalışma koşullarının düzenlenmesi Önerilir.

Anahtar Kelimeler: Kuşak, hemşirelik bakımı, yaşlanma, algı 


\section{INTRODUCTION}

Older people are generally defined according to a range of characteristics including: chronological age, change in social role and changes in functional abilities. Older people may be defined as those over 60 years. ${ }^{[1,2]}$ The number of older people is expected to reach 2 million by the year 2050 in the world. ${ }^{[3]}$ Similarly, the Turkish population is increasingly aging. In $2016,8.3 \%$ of the overall population was older than 65 years old. Predictions are that this rate will increase to $20.8 \%$ in $2050 .{ }^{[4]}$ These estimates have stimulated research and discussions around aging, chronic disease management, and care of older people. ${ }^{[5,6]}$ Also, these growing numbers of older persons increased the need for qualified nurses to provide specialised care.

Nurses are the health personel who play an active role in the identification of older patients' needs, care, and rehabilitation. Nurses can develop positive or negative attitudes towards care for older people. Quantitative studies have detected that nurses attitudes toward aging are multi-dimensional and influenced by many factors, including each individual's experiences, culture, values, and beliefs. At the same time age is an important demographic variable in studies investigating perception towards the elderly. ${ }^{[2,7,8]}$ Higgins et al. reported that nurses prefer working with young people to work with older people. ${ }^{[9]}$ However, Coffey, \& Whitehead (2015) reported that health care assistants have a positive attitude towards the elderly care. ${ }^{[10]}$

Attitudes toward older people vary with changing societies and generations, and health personnel are influenced by these transformations. ${ }^{[6,11]}$ Individuals growing up in different generations represent the values of their own generation. Members of generation X (39-51 age group) are unconventional and open to new ideas. They try to balance parenthood roles, such as being a partner and a mother. In this time period, when women entered the workforce more frequently than before, individuals prioritized their families. Members of generation $Y$ (24-38 age group) were raised during the welfare period. They are sociable and sharing. They grew up in an environment where family values were concentrated on children. These individuals were raised by more attentive families, and they prioritize balancing work and family life. ${ }^{[12-14]}$ Finally, perception of older people is shaped by cultural values. In some societies, the elderly person is perceived as a burden because needs for health and care services increase with aging. In other societies, older person is viewed as a positive process accompanied by growth in wisdom and maturity. ${ }^{[2,15]}$ Turkish society has always valued and protected older people. Because older people form an essential element of the Turkish family ideal, meeting the needs of older people remains the family's responsibility: the family continues to be the primary psychological and social support system. ${ }^{[5,15]}$ At the same time, downsizing of families and consumerism increases along with industrialization, the escalating number of people with chronic disease that accompanies longevity, and the increased need for care, can lead to weakened family ties and problems associated with older people care..$^{[2,16,17]}$ Studies have been conducted to examine the views of nurses toward their job and profession. ${ }^{[7,8]}$ Also, studies were conducted about ageism and nurses' view for elderly. But there are only limited nursing about nurses' perceptions and working experiences care of older people in Turkish society. ${ }^{[18-22]}$ Generation refers to specific groups of people with a major characteristic in common. Understanding the differences between generations is crucial to improving care in geriatric clinics. For this reason, the research question in the study was: What are two age chorts of nurses' perceptions and working experiences about care for the elderly. The aim of this study was to determined different age groups clinical nurses' perceptions and working experience towards care for older people in Turkey.

\section{MATERIAL AND METHOD \\ Study Design}

The study was conducted the qualitative approach to compare perceptions and working experiences of clinical nurses in different generation about caring for the older people (65+ years).

\section{Study Site}

Participants were nurses working with older people in internal medicine and surgery clinics. We condected the research at the internal medicine and surgery clinics because of deficiencies in geriatric care clinics, most of nurses give care to older people in most of clinics in hospitals in Turkey. A thematic-based analysis was used to examine whether nurses' perceptions and experiences on working with older people vary by generation.

\section{Participants}

The age groups are divided into generations, which in this research is Generation X and Generation Y. The nurses included in generation Y group were born between 1980 and 1994, ages 24 to 38 years old. The nurses included in the generation X group were born between 1965 and 1979, ages 39 to 51.[22] The inclusion criteria is to become as a nurse in Turkey, be working in internal medicine and surgery clinics, nurses with at least 1 year experience, prior experience caring for older people and age groups representing the $X$ and $Y$ generations. Nurses who did not give consent for voice recording $(n=26)$, who only worked night shifts $(n=20)$, or who had less than one-year experience $(n=10)$ were not included in the study. Further, nurses working in pediatrics, the intensive care unit, bone marrow transplantation units, psychiatry units or polyclinics were excluded from the study. In our study, no sample selection was made, and the saturation of the data was taken account. ${ }^{[23]}$ Specifically, the research sample consisted of 68 nurses working at a university hospital.

\section{Data Collection}

The study was conducted between May 2018 and July 2018 at the clinics of a university hospitals in the city center of Ankara. A short demographic questionnaire was used. A demographic form consisted of 7 questions including gender, age, years of 
experience, and clinic base. A semi-structured interview form was developed by two the researchers on the basis of their reviews of the relevant literature. ${ }^{[9-11,14,22]}$ This form consisted of questions on nurses' perceptions and working experiences toward care for older people. Open-ended interview questions were as follows:

- What images do you have about older people in hospital?

- What are your feelings about working with older people?

- What are your experiences about providing care for the older people?

- How do you think older people health services should be?

Data were collected in the clinic environment during and after work hours. Voice recorders and note-taking were used during the interviews. Each interview took approximately 30-40 minutes for each participant. Each participant was interviewed once. Face-to-face interviews were carried out in a meeting room. Data were collected by researcher who has clinical experience and researches in gerontology.

\section{Data Analysis}

SPSS 21 was used for the statistical analysis of quantitative data. Percentage and mean values were calculated. The Braun and Clarke (2006) approach for conducting thematic analysis of qualitative data was used. ${ }^{[24]}$ This approach consists of several steps as detailed here. (i) Familiarizing yourself with the data: Voice recordings of the in-depth interviews were fully transcribed verbatim. Participants' verbal expressions read and reread data to ensure understanding of the content. Age groups were analyzed separately. (ii) Generating initial codes: Data were grouped based on content, and accuracy with the original version was maintained and interpreted on the basis of the research questions. Then the codes were collated into potential themes in independently by two of the authors. (iii) Searching for themes: All codes were grouped into categories based on how they were related and themes and subthemes were found by two of authors. Internal and external consistency principles were considered during thematic coding. Within the overarching themes, subthemes were identified for each group. (iv) Reviewing themes: Lastly, each theme was analysed in detail based on their importance in answering the research questions. Subthemes supported by direct quotations that could most accurately emphasize/identify nurses' perceptions and working experiences. (v) Defining and naming themes: The names of themes were created. (vi) Finally, the report was produced.

The trustworthiness of the findings was considered. Interview questions were reviewed by three experts (Turkish education expert, academician and qualitative analyst) and revised in light of the expert views. Then the interview question was tested, by the first author and one nurse ahead of the interviews to assure confirmability. Participants' verbal expressions were transferred to a separate Microsoft Word document without adding any comments. All the interviews were conducted by a researcher with clinical experience and research experience in gerontology for credibility of the study.

\section{Ethics}

Ethical consent was obtained Yıldırım Beyazıt University Social and Humanities Ethics Committee (Date: 09.12.2016, Decision No: 398). The study was carried out according to the principles of the Helsinki Declaration. Data were collected from nurses who gave informed consent and voluntarily participated in the study.

\section{RESULTS}

Nurses' sociodemographic characteristics are shown in Table 1. Three themes were decided upon as a result of the qualitative analyses for each group. While X generation nurses seems to have accepted that older people are difficult to care for both negative and positive emotional responses. There remained problems with the care time working with older people. It is stated that $X$ generation nurses try to understand older people through empathy and that better conditions for older people should be provided. When $Y$ generation nurses gave care to older people, they experienced ambivalent feelings and they categorized the elderly in workload and felt that improvements in the health care system as well as employment conditions should be made. Three subthemes for generation $X$ and $Y$ are shown in Table 2 . Words frequently repeated by participants were grouped using the word cloud method during voice recording. Members of generation $\mathrm{X}$ emphasized the words 'care' and 'insufficient', whereas generation Y nurses repeated "care" and "dependent".

\begin{tabular}{lcc}
\hline Table 1. Characteristics of nurses $(\mathrm{n}=68)$ & & \\
Characteristics & Frequency & Percentage \\
\hline Sex & 63 & \\
Female & 5 & 93.1 \\
Male & & 6.9 \\
Generation & 33 & \\
X generation & 35 & 48.5 \\
Y generation & & 51.5 \\
Education status & 56 & \\
Bachelor's degree & 12 & 82.4 \\
Higher education graduate & & 17.6 \\
Marital status & 48 & \\
Married & 20 & 70.6 \\
Single & & 29.4 \\
Clinic stationed at & 36 & \\
Internal medicine & 12 & 52.9 \\
Surgery & & 26.5 \\
Any children & 46 & \\
Yes & 12 & 67.6 \\
No & & 32.4 \\
Living with elderly people & 8 & \\
Yes & 60 & 87.6 \\
No & & \\
\hline
\end{tabular}

Table 2. Themes for different generation nurses

Themes for $\mathbf{X}$ generation nurses

Emotional responses

Care time

Provide resources for older patients

Themes for $\mathbf{Y}$ generation nurses

Categorized of older people

Increasing workload and problem of time

Need for holistic care 


\section{Themes for Y Generation}

The general themes of generations $\mathrm{Y}$ were: increasing workload and time problems, categorization of older people, and finally, the need for holistic care.

Increasing workload and the problem of time: Nurses reported that working with older individuals is difficult and increases workload. There were many reasons for the difficulties experienced by nurses. Due to time problems and other intensive nursing practices, older people are increasing nurses' workload. Additionally, older people had many chronic diseases, dependency of elderly people to others and physical limitations are reported as the causes of workload. Generation $\mathrm{Y}$ nurses noted that because older people need more care, nurses' workload has increased and they have had problems keeping up with other nursing practices that also need to be managed.

"There are many differences between providing care for an individual who is 20-30 years old and for individuals who are 60 years old and above. This is because there are many complications involved in elderly diseases. For instance, if the elderly patient is admitted to the cardiology clinic, other units such as internal medicine, nephrology, and endocrine monitor the patient too. Following up all these influences our workload" (34 years old, female).

Categorization of older people: Nurses stated that individual differences of the elderly affect their perception of care. Most of nurses reported that they tried to empathize. However, the nurses have reported that they have been exhausted. Nurses defined categories in relation to older people. Nurses stated that caring for some older people is difficult and more demanding than caring for other patients and some people change in their personalities through the process of disease and development of physical problems. Some older people are no different to others.

"Sometimes during the process of aging, people feel lonely and useless. They are dependent on care, and sometimes they may try to attract the attention of other individuals surrounding them..... But some older people are no different than others and are so cute" (26 years old, female).

Need for Holistic Care: Most of the nurses considered that health services for the elderly were insufficient. Nurses experienced difficulties in the care of the elderly because of the conditions in the hospitals. Generation Y nurses emphasized the importance of holistic care for older people and the need for recruiting personel in this area. Because of multiple needs, it was considered necessary to provide holistic care and to provide teamwork with trained personnel.

"Care programs for the elderly should be organized holistic approach. However, since there is no space in geriatric services, such care cannot be provided. Care programs should include both medical treatments and activities that cannot be carried out due to physical inadequacies (all forms of logistic support including eating, cleaning, shopping, and a telephone hotline") (32 years old, female)

\section{Themes for X Generation}

The general themes of generations $X$ were: care time, emotional responses, and provide resources for older patients.

Care time: Nurses stated that they are aware of the needs of older people. This awareness affects workload positively so the elderly did not increase their workload. However, nurses explained that they had time problems while caring for elderly people. They must have more time to look after older people. Because diseases increased in line with aging so the elderly often were dependent on care. However, nurses reported that nurses don't have enough time for older people care because of other intensive nursing activities.

"The elderly cannot immediately carry out what they are told. For example, you tell her 'take your medicine', but she cannot open the box and take it. Most of the time, she needs help in standing up. It is not difficult to support them but you have to spend for more time for older people. Sometimes because of the time problem, we are not as interested in their needs" (42 years old, female).

Emotional responses: Nurses had positive and negative emotional of working with older people. Nurses reported that they tried to empathize with older people and that they mostly felt happy and pleased. Some nurses said that elderly people became in need of care and fond. Nurses defined the feeling of pity and sadness when they gave care to these patients and that they thought they could be like this when they got older.

"First, I put myself in their shoes. For sure, I empathize with other patients too, but the part when I envision myself getting older makes the elderly more important for me. Second, I feel pleased feel happy while giving them care. Sometimes I feel sadness for them because I think older people feels insufficient in meeting her needs, gets exhausted easily, needs help" (50 years old, female).

Provide resources for older patients: Nurses aware of the needs of the elderly. However, participants experienced insufficient working circumstances while caring for older people. Generation X nurses noted that care programs for the elderly should be organized according to the needs and care of the patient and elderly home care services should be improved. Nurses believed that elderly are better cared for in old people's homes. They needed activities to diminish dependency of the older persons.

"It became better over the last few years, but still the number of elderly home care services should be increased. There should be frequent medical examination and controls. Health services should be easily accessed. There should be support for transportation, shopping, and care of the elderly" (44 years old, female)

\section{DISCUSSION}

Although general attitudes toward older people were found to be positive, views regarding care at hospitals may be negative as a result of health problems, hospitalization processes, functional regression, and accompanying comorbidities. ${ }^{[25]}$ In our study nurses had positive and negative perceptions towards older people care. Similar to our study. Higgins et al. reported that 
nurses prefer working with young people to work with older people. ${ }^{[9]}$ However, in the other study, were found that the attitudes of nurses generally were positive. ${ }^{[2]]}$ Perceptions can be negatively influenced by the under resourced care environments experienced when working with older people. In our study, both generations nurses described older people are difficult to care for. Life changes arising from chronic diseases were considered to affect both older people and their caregivers. Hospitalization for the older person can represent the beginning of functional decline and increased dependency. For this reason, nurses interpreted older people with chronic disease as increasing the burden of care. Health workers are interested in pathological aging rather than healthy aging. In this case, it is seen that they work more patient-centered than individuals.

Nurses from both generations in our study emphasized increasing workload and nurses noted that the problem of time is due to this workload increase. Contexts such as physical and mental loss, dependency, and the need for another person in daily care make aging an uneasy period. Similar to our study Smythe at al. expressed lack of time to care. ${ }^{[27]}$ In the study by Higgins and colleagues, nurses did not pay attention to the care of older people and perceived it as a waste of time. ${ }^{[9]}$ It has also been determined that nurses cannot provide the required care for older people due to time limitations. ${ }^{[28]}$ Intensive workload and inadequate role preparation may cause challenges in young nurses. Also generation $\mathrm{X}$ nurses have time management problems. Generation Y nurses don't like to waste time. ${ }^{[22]}$

Although nurses in our study empathized working with older people, and nurses experienced more feelings of ambivalece, sadness, happy, and exhaustion. Smythe and colleagues carried out a study on nurses working with dementia patients. [27] Under the themes of responsibilities and vacancies, nurses explained that they felt sorry for limiting the extent of their relationships with the older people, as well as providing less than attentive and person-focused care due to other priorities such as administering medications and catheterization. ${ }^{[27]}$ The study condected by Kae and Gyeong was identified wisdom and maturity as one of the four themes among the perceptions of aging. ${ }^{[29]}$ It is stated in a systematic review that nurses' have coexisting positive and negative attitudes towards older adult care. ${ }^{[30]}$ Generation $\mathrm{X}$ nurses, did not have any preconceived ideas and mentioned the emotional responses to older people. They felt happy and empathic when giving care due to the respect and attention given to older people. However, generation $\mathrm{Y}$ nurses evaluated elderly people by categorically dividing them according to workload. One possible reason why generation $Y$ nurses expressed exhaustion more often could be related to members of this group being less willing to work and belief in having a more flexible working method.

All nurses expressed insufficient health care for elderly in our study. Nurses mentioned that care services for older people were inadequate and advised developing a holistic care service for patients and increasing home care services as well as increased personnel recruitment. Members of generation $X$ mentioned home-care services more frequently because they wanted to work in environments with specific boundaries. Generation Y nurses highlighted the concept of recruitment in response to their belief in team-work. Likewise, in the qualitative study carried out by Hunter and colleagues, nurse assistants emphasized the need to develop a holistic care approach and to provide psychological support for the elderly. ${ }^{[31]}$ Organizing the health care system to care to for the needs of the population of older people is important in view of the health problems and difficulties that arise from aging. InTurkey, necessary arrangements should be made for developing new service models that can meet the problems and needs of an increasingly aging society. Older people should be supported with live-in care and professional assistance. Findings of our study reveal the current short comings in this area in Turkey.

\section{CONCLUSION}

Nurses perceptions towards older people care are complex and contradictory. Age as a demographic variable emerged as influences on nurses' attitudes and nurses' approaches to older patients care. This study determined the perceptions of different generation nurses' on caring for older people. Whereas respect, protection, and importance given to older people in Turkish society are still safe guarded, aging-related diseases and the burden of care are regarded as problems. This research determined differences between generations of nurses in their care of older people. We suggest that focus should be given to the development of work force support and supervision. The number of older people in need of care is expected to increase as the population continues to age and politicians both nationally and internationally emphasize the goal of quality of care for older people. Findings suggest that improved organization of health care services and greater opportunities for continuing education related to care of older people and working conditions should be implemented in Turkey to improve nursing care.

\section{ETHICAL DECLARATIONS}

Ethics Committee Approval: Ethical consent was obtained Yıldırım Beyazıt University Social and Humanities Ethics Committee (Date: 09.12.2016, Decision No: 398).

Informed Consent: All patients signed the free and informed consent form.

Referee Evaluation Process: Externally peer-reviewed.

Conflict of Interest Statement: The author(s) declared no potential conflicts of interest with respect to the research, authorship, and/or publication of this article.

Financial Disclosure: The authors declared that this study has received no financial support.

Author Contributions: All of the authors declare that they have all participated in the design, execution, and analysis of the paper, and that they have approved the final version. 


\section{REFERENCES}

1. World Health Organization. Aging and health. Published 2018. Accessed August 10, 2018. https://www.who.int/news-room/fact-sheets/detail/ ageing-and-health.

2. Kalınkara V. Geleneksel toplumdan modern topluma yaşlı:Yaşlının statüsü ve geleceği. International Symposium on Relations of Turkey Belgium and Co -Exhibition of Turkish Arts. Brussels Belgium. 2012.

3. World Health Statistics. 2012. http://www.who.int/gho/ publications/ world_health_statistics/EN_WHS2012_Full. Pdf.

4. Turkish Statistical Institute Population Projections, 2013-2075. http:// www.turkstat.gov.tr/PreHaberBultenleri.do?id=15844 [updated 10 Nov 2015; cited 12 Nov 2018].

5. Canatan A. Social values and elderly people. Elderly Problems Res J 2008;71.

6. Wold GH. Basic geriatric nursing. 3. ed. Philadelphia:Mosby. 2004;3-20.

7. Hayes LJ, O'Brien-Pallas L, Duffield C, et al. Nurse turnover:A literature review - an update. Int J Nurs Stud 2012;49(7).

8. Heinen MM, Van Achterberg T, Schwendimann R, et al. Nurses' intention to leave their profession:A cross sectional observational study in 10 European countries. Int J Nurs Stud 2013;50:174-84.

9. Higgins I, Riet DVP, Slater L, Peek C. The negative attitudes of nurses towards older patients in the acute hospital setting:A qualitative descriptive study. Contemp Nurse. 2007;26(2):225-37.

10. Coffey A, Whitehead N. Healthcare assistants' attitudes towards older people and their knowledge about ageing. Nurs Older People. 2015;27 (1):24-30.

11. Kagan SH, Melendez-Torres GJ. Ageism in Nursing. J Nurs Manag 2015;23.

12. Kupperschmidt B. Multigenerational employees:strategies for effective management. Health Care Manager. 2000;19:65-76.

13. Weston M. Coaching generations in the workplace. Nurs Adm Q 2001;25:11-21.

14. Takase M, Oba K, Yamashita N. Generational differences in factors influencing job turnover among Japanese nurses:An exploratory comparative design. Int J Nurs Stud 2007;46:957-67.

15. Ministry of Family and Social Policy. The status of the elderly in Turkey and aging national action plan implementation program. Ankara. Published 2013. Accessed June 20,2018. https://eyh.aile.gov.tr

16. Bloom DE, Jımenez E, Rosenberg L. Social protection of older people global population ageing: peril or promise? World Economic Forum. 2012;83-88.

17. Riley MW, Riley JW. Age integration:conceptual and historical background. Gerontologist. 2000;40.

18. Courtney M, Tong S, Walsh A. Acute-care nurse's attitudes toward older patients:a literature review. Int J Nurs Pract 2000;6(2):62-9.

19. Allan LJ, Johnson JA, Emerson SD. The role of individual difference variables in ageism. Pers Indiv Differ 2014;59:32-7.

20. Lou B, Zhou K, Jin EJ, Newman A, Liang J. Ageism among College Students:A Comparative Study between U.S. and China. J Cross Cult Gerontol 2013;28:49-63.

21. Ünalan D, Soyuer F, Elmalı F. Evaluation of the attitudes of the geriatric care center workers towards elderly patients. Kafkas J Med Sci 2012;2(3):115-9.

22. Betz CL. Generations X, Y, and Z. J Pediatr Nurs 2019;44:7-8.

23. Türnüklü $A$. Eğitim bilim araştırmalarında etkin olarak kullanılabilecek nitel bir araştırma tekniği:görüşme. Kuram ve Uygulamada Eğitim Yönetimi. 2000;24(24):543-59.

24. Braun V, Clarke V. Using thematic analysis in psychology. Q Res Psychol 2006;3:77-101.

25. Akdemir N, Çınar Fí, Görgülü Ü. Perception of ageing and ageism. Turk J Geriatr 2007;10:215-22.

26. Kang Y, Moyle W, Venturato L. Korean nurses' attitudes towards older people with dementia in acute care settings. International Journal of Older People Nursing. 2011;6 (2):143-52.

27. Smythe A, Jenkins C, Galant-Miecznikowska M, Benthamc P, Oyebode J. A qualitative study investigating training requirements of nurses working with people with dementia in nursing homes. Nurse Educ Today. 2017;50:119-23.
28. Blomberg K, James I, Kihlgren A. Meanings over time of working as a nurse in elderly care. Open Nurs J 2013;7:107-13.

29. Kae-Hwa Jo, Gyeong-Ju An. Perception of aging among Korean undergraduate nursing students. Acta Paul Enferm. 2012;25(1):35-40.

30. Rush KL, Hickey S, Epp S, Janke R. Nurses' attitudes towards older people care:An integrative review. J Clin Nurs 2017;26(23-24):4105-16.

31. Hunter PV, Hadjistavropoulos T, Sharon K. A qualitative study of nursing assistants' awareness of person-centred approaches to dementia care. Ageing and Society. 2016;36 (6):1211-37. 